\title{
DON INGLIS
}

\section{G P Barton*}

I first came to know Don Inglis as an undergraduate at Victoria University of Wellington. He came to Law studies after completing a BA, specialising in Modern Languages. After completing an LLB degree he immediately moved on to postgraduate study in Law taking an LLM with First Class Honours. In those years he was a fellow student and friend of Sir Thomas Eichelbaum, later Chief Justice of New Zealand, and of Sir Michael Hardie Boys, later a Judge of the Court of Appeal and Governor-General of New Zealand. For many of his student years he was working as a Law Clerk in Wellington. While in practice with the Wellington firm of C J O'Regan \& Arndt, Don won a Commonwealth Fellowship and studied at the University of Chicago and also at the University of Michigan.

Having returned to New Zealand, he was appointed a Senior Lecturer in Law at Victoria. Previously, Don had been a student of mine both at the undergraduate and at the postgraduate levels. We kept in close touch with each other after Don went overseas. It was a particular pleasure to have him as a colleague in the Faculty, especially as he and I took advantage of our terms of employment which allowed us to practice as barristers. For many years we shared the same barristers' chambers. Occasionally we would be representing parties with the same or similar interests: once or twice we would be representing opposing parties.

The collegiate atmosphere in the Faculty when Don joined it was relaxed and most congenial to Don's temperament. It was not at all unusual for us to invite students working in the Law Library to come to our studies for a casual cup of coffee. In those relaxed conversations law occupied centre stage. That gave Don and his colleagues a clear indication of the areas of difficulty for students and how those difficulties could be overcome. It was typical of him that he immediately noticed the lack of suitable textbooks in subjects for which he had a teaching responsibility. Like some of his colleagues in the Faculty, he went to the trouble to prepare materials for the use of his students. The first publication was a set of cases and materials on Conflict of Laws (1958), which was quickly followed up by his textbook on Conflict of Laws (1959). In writing that book, Don made it clear that he had tried as far as possible to avoid any theoretical expositions of the subject, but went so far as to say that:

* Queen's Counsel, Wellington. 
On some of the more controversial topics I have been rash enough to seize the opportunity to state my own views.

In stating those views, Don was influenced to a large degree by considering the matters which were likely to be of the greatest current practical interest to New Zealand students and practitioners.

In writing the case book and textbook, Don displayed his amazing capacity to analyse source materials of various kinds and to present the fruits of his consideration in a clear and readable style. He was a quick worker. One of the secretaries whom Don thanked in his preface to Conflict of Laws recalls that the draft materials on which she worked rarely contained handwritten alterations or amendments.

But it was in the context of a new subject which had been introduced into the curriculum for Law students that Don really made his mark as an author. This was Family Law. With scarcely a pause from writing his textbook on Conflict of Laws, Don turned to the writing of the first attempt to deal with Family Law in New Zealand "as a composite whole". In a remarkable academic feat, Don embarked upon the teaching of a completely new subject and at the same time writing a completely new textbook. Four years later Don published a supplement to Family Law which took account of three very important statutes - the Matrimonial Proceedings Act; Matrimonial Property Act; and Destitute Persons Amendment Act (all enacted in 1963).

The writing of textbooks is rarely carried through in total academic isolation. As Don points out in his prefaces, particularly in the preface to Family Law (1960), he had co-operation from some of his academic colleagues. I vividly remember the many discussions with Don about the substance of his commentary on Family Law - in his preface Don spoke of my having "cheerfully undertaken the harrowing task of reading the typescript from beginning to end".

Somewhat to the surprise of Don's friends, who thought that he would eventually be appointed to the (then) Supreme Court, Don accepted appointment as a District Court Judge with a Family Court warrant. In that role he showed his total mastery of Family Law. He continued to work with great speed, delivering judgments on difficult and sometimes controversial issues. His mana as an expert in Family Law must have given some of his judicial colleagues an inferiority complex as they struggled with new arguments, with conflicting decisions, and with new ideas.

It is rare for an author to maintain such a pitch of concentration on a subject to the very end of his life. But that is what it was for Don. A chance encounter with a representative of the publisher of a set of Law Reports disclosed that Don was undertaking a writing project on Family Law in which he hoped to draw on the proposed publication for a series of articles or case notes. The publishers asked for samples of what had already been written and immediately began negotiating with Don for a contract for what became Family Law in the 21st Century. The old procedures were replaced by the new technology. A few months before his death Don wrote about his amazement that the first sample chapters of his book were returned to him almost the next day in the form of finalised printed page proofs complete with Tables of Statutes, Tables of Cases, and an Index. The only 
proofreading that he had to do was checking the cross-references. All of that was grist to Don's approach to writing. It was no wonder that his book, Family Law in the 21st Century, was declared the joint winner of the Legal Research Foundation's annual J F Northey book prize. As the Judges said, the text carried with it Don Inglis' unparalleled New Zealand experience as academic, legal author, and Family Court Judge.

In this tribute to Don, I have confined myself principally to Don's specialised work and writing. Such an emphasis is appropriate in a Law Review of a University in which Don was a foremost exponent of a special branch of our law. 
